\title{
Perforacion divertículo vesical por apéndice epiploico
}

\author{
Díez-Caballero Alonso F, Benejam Gual J. \\ Servicio de Urología. Fundación Hospital de Manacor. Palma de Mallorca
}

Actas Urol Esp. 2007;31(4):429

$\mathrm{P}$ aciente de 63 años con antecedentes personales de EPOC y funduplicatura laparoscópica tipo NISSEN por hernia diafragmática paraesofágica incarcerada.

Diagnosticado de gran divertículo vesical y litiasis ureteral de gran tamaño. Previa intervención programada, presenta ingreso urgente por hematuria macroscópica anemizante que obliga a revisión endoscópica urgente hallando gran divertículo vesical perforado y por apéndice epiploico sigmoideo. Se realiza laparatomía media (Fig. 1) con exéresis de divertículo vesical y apéndice epiploico así como ureterolitotomía izquierda.

Correspondencia autor: Dr. F. Díez Caballero Alonso

Servicio de Urología. Fundación Hospital de Manacor. Ctră.

Manacor-Alcudia, s/n. 07500 Manacor. Palma de Mallorca

Tel.: 971847000

E-mail autor: fdcaballero@yahoo.com

Información artículo: Imágenes en Urología

Trabajo recibido: marzo 2006

Trabajo aceptado: abril 2006

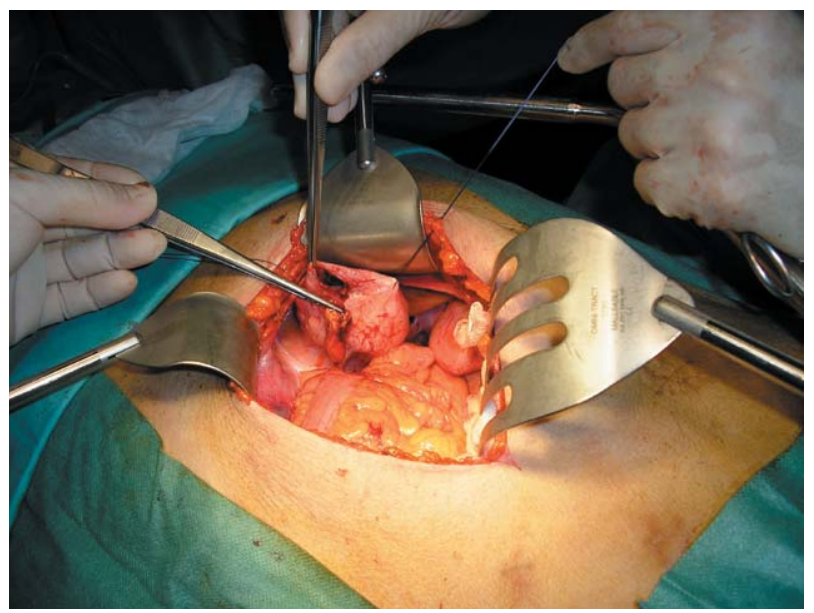

FIGURA 1 